\title{
Stable isotope analysis of soft tissues from mummified human remains
}

\author{
Angela L. Lamb \\ NERC Isotope Geosciences Facility, British Geological Survey, Keyworth, Nottingham NG12 \\ $5 G G, U K$.
}

\begin{abstract}
Mummies are faunal remains that include the preservation of soft tissues; such as skin, muscle, nails and hair as well as bone. These soft tissues are generally rich in collagen or keratin proteins and thus provide potentially suitable material for stable isotope studies. When preserved, such tissues can provide high-resolution information about the diet and migration of humans in the weeks and months before death. Hair, nails and soft tissue provide short-term (months) dietary information in contrast to bone which will represent 520 years of dietary history prior to death, depending on the bone analysed. Such highresolution data can answer questions on the season of death, seasonality of food resources and the movement and relocation of people. This review begins with a summary of the most common isotope techniques $\left({ }^{13} \mathrm{C} /{ }^{12} \mathrm{C},{ }^{15} \mathrm{~N} /{ }^{14} \mathrm{~N}\right)$ and the tissues concerned, followed by an analysis of the key questions that have been addressed using these methods. Until relatively recently work has focused on bulk protein isotope analysis, but in the last 10 years this has been expanded to on-line compound-specific amino acid analysis and to a wider variety of isotopes $\left({ }^{18} \mathrm{O} /{ }^{16} \mathrm{O},{ }^{2} \mathrm{H} /{ }^{1} \mathrm{H}\right.$ and $\left.{ }^{34} \mathrm{~S} /{ }^{32} \mathrm{~S}\right)$ and these applications are also discussed.
\end{abstract}

Key Words: mummies, stable isotopes, soft tissues, hair, skin, nails 


\section{Introduction}

The mummification of soft tissues occurs both naturally (spontaneous) and with post-mortem human intervention (artificial or anthropogenic). By definition mummies are remains that include the preservation of soft tissues (in addition to bone) such as skin, muscle, nails and hair. These soft tissues are generally rich in protein, e.g. collagen (and possibly some elastin) in skin, keratin in hair and nails, and myofibril (myosin-actin complex) and collagen in muscle, and thus provide potentially suitable material for stable isotope studies. Mummification will naturally occur in environments that are anaerobic, extremely arid or extremely cold or a combination of these conditions and can be exacerbated by heavy metal contamination of the body and through chelation (See Aufderheide, 2003). For Ancient Egypt at least, the methods of artificial mummification are very well understood (Aufderheide, 2003; Metcalfe, 2008) and involved several stages; namely: the removal of the internal organs, desiccation of the body using natron (a naturally-occurring mixture of sodium salts) and the application of various preservative resins (typically beeswax, animal fats, pine resin and bitumen). Artificial mummification was widespread in ancient Egypt, particularly during the Old Kingdom (2649-2152 BC) and the Late Period (712-332 BC), but by the Late Ptolemic (200-30 BC) and through the Roman period (30 BC-AD 400) it had started to decline; stopping altogether with the introduction of Islam in the $7^{\text {th }}$ century $A D$ (Davies, 2011). Artificial mummification was also widely practised in The Sudan (Nubia), Mexico, Chile, Argentina, Peru and Yemen amongst others (for review see Aufderheide 2003, 41-71).

The value of examining mummified remains using scientific methods was pioneered by a research group lead by Rosalie David at the University of Manchester, UK in the 1980s (David, 1982, 1986). David and her colleagues saw the vast untapped potential for reconstructing social, cultural and health conditions in past societies from the application of established scientific methods, including a wide range of molecular, biochemical and biomolecular techniques. Early discussions of the possibilities took place at the first World Congress on Mummy Studies in 1992 and a new field was born (see Aufderheide, 2003 for more discussion). The application of stable isotope methods to soft tissues began in earnest in the 1990's with pioneering work from research groups lead by Christine White on Nubian 
mummies (e.g. White 1993; White and Schwarczz 1994) and by Arthur Aufderheide and Larry Tieszen on South American mummies (Aufderheide et al. 1994; Tieszen et al. 1995).

There is a long history of isotope studies on bone collagen from mummified remains, (see Thompson et al., 2005 for review), but stable isotope applications on soft tissues and hair developed more recently. Soft tissue preservation is relatively rare and when it occurs there is a risk that the tissue is contaminated with the products used during mummification and also by post-excavation preservation during museum conservation. Most of the ancient Egyptian mummies that have been analysed come from the later periods of Egyptian history when the use of various resins was common. As these resins have inherent sources of the elements commonly analysed for stable isotopes ( $\mathrm{C}$ in particular but also potentially $\mathrm{N}$ and S), there remains the issue of how to completely remove the resins and how to do this without affecting the original isotope ratios of the tissues. White et al. (1999) attempted this on ancient Egyptian soft tissue and hair, using various combinations of chloroform and methanol and judged their success by the degree of change in the $\delta^{13} \mathrm{C}$ values pre and post treatment. In the absence of true baseline values for ancient tissues, however, it is impossible to fully determine the success of these methods.

The ability to analyse the original stable isotope ratios in mummified soft tissues will enable more opportunities to elucidate short term diet. Most studies of palaeodiet on ancient human remains utilise bone collagen as it is often the most abundant tissue preserved. Hair keratin is an alternative proteinaceous material that can be less subject to degradation than bone and dentine and the proteins can potentially be preserved for 1000 's of years (e.g. Lubec et al., 1987). Hair, nails and soft tissue will provide short-term dietary information in the months leading up to death as opposed to bone which will average 5-20 years of diet prior to death depending on the bone analysed (Hedges et al., 2007, Hill and Orth, 1998). Such high-resolution data can answer questions on the season of death, seasonality of food resources and movement and relocation of people. This review begins with a summary of the isotope techniques and the tissues concerned, followed by an analysis of the key questions that have been addressed with these methods. It finishes with a look at the more unusual isotopes applied to soft tissues and also explores work using compound specific isotopes. Table 1 comprises a list of published studies on soft tissues with mean stable isotope values. 


\section{Isotope techniques}

Palaeodietary reconstruction is based on the principle that the isotope composition of consumed food (dietary proteins, carbohydrates and lipids) is transformed by the body and preserved in human tissues (e.g. bone collagen, hair, and dentine) (Sealy, 2001). Until relatively recently work has focused on bulk protein isotope analysis, but due to recent advances in mass spectrometry, this has been expanded to on-line compound-specific amino acid analysis, enabling specific targeting of amino acids.

For carbon isotopes (expressed as $\delta^{13} \mathrm{C}$ ), human tissues will reflect the $\delta^{13} \mathrm{C}$ values of the plants and animals consumed (with some isotope fractionation/alteration) and the distinction in $\delta^{13} \mathrm{C}(\sim 12 \%$ ) that exists between the two major plant photosynthetic groups can be observed within these tissues $\left(C_{4}=-15 \%\right.$ o to $-9 \%$, $C_{3}=-33 \%$ o to $-23 \%$ o) (O'Leary, 1988). Most plants fall under the $C_{3}$ pathway (including for example wheat and barley) $C_{4}$ plants are adapted to grow in areas of high temperatures, drought and $\mathrm{CO}_{2}$ and/or nitrogen limitation and include many tropical grasses and cereal crops such as maize, sorghum and millet. $\delta^{13} \mathrm{C}$ can also potentially distinguish between marine and terrestrial sources of carbon in $\mathrm{C}_{3}$-plant dominated environments (Schoeninger and DeNiro, 1984).

Nitrogen isotopes (expressed as $\delta^{15} \mathrm{~N}$ ) preserved in human tissues also depend largely on diet (predominantly protein), but environmental and metabolic factors (such as water and food stress or soil nitrogen cycling) are also influential (Heaton, et al. 1986; Fuller, et al. 2005). $\delta^{15} \mathrm{~N}$ will primarily reflect the vegetation at the base of the food chain and then incorporate a step-wise increase through each trophic level, thus carnivores will have $\delta^{15} \mathrm{~N}$ about +3 to $+5 \%$, higher than those of herbivores from the same ecosystem and thus it is often possible to estimate trophic level (Schoeninger and DeNiro, 1984). Extended food chains, involving several carnivorous steps, produce the highest $\delta^{15} \mathrm{~N}$ values and long food chains are typical of aquatic systems and thus relatively high $\delta^{15} \mathrm{~N}$ values can suggest marine protein in the diet. By analysing herbivore collagen, it is possible to estimate the $\delta^{13} \mathrm{C}$ and $\delta^{15} \mathrm{~N}$ ratios of the baseline vegetation of an archaeological site, but in their absence, baseline values have to be assumed. Most terrestrial plants have $\delta^{15} \mathrm{~N}$ values of $\sim 0$ to $+5 \%$, thus herbivores might expect to have values of $\sim+4$ to $+9 \%$, and carnivores $\sim+8$ to $+13 \%$ o. Heaton et al. (1986) demonstrated that the $\delta^{15} \mathrm{~N}$ of herbivores are strongly correlated to precipitation amounts with animals living in arid areas having relatively high $\delta^{15} \mathrm{~N}$. This has 
been replicated in other arid areas: Sealy et al. (1987), found herbivores with $\delta^{15} \mathrm{~N}$ of $>$ $+10 \%$ in areas with $<400 \mathrm{~mm}$ of rainfall, although there is still debate in the literature about what the actual mechanism is (Dupras and Schwarczz, 2001). Freshwater fish in the diet are more difficult to ascertain from carbon and nitrogen isotope ratios as they will give similar $\delta^{13} \mathrm{C}$ and $\delta^{15} \mathrm{~N}$ to terrestrial mammals in the diet.

The addition of sulphur isotopes (expressed as $\delta^{34} \mathrm{~S}$ ) may allow freshwater fish in the diet to be discriminated more easily within tissues if the baseline $\delta^{34} S$ for riverine sulphates can be established and are sufficiently different to terrestrial values (e.g. Nehlich et al. 2010; Privat et al. 2007). Marine primary producers have $\delta^{34} S$ between +17 to $+21 \%$ o reflecting marine sulphates in contrast to terrestrial organisms which have much lower, more variable, values reflecting the underlying soil processes ( -7 to $+8 \%$; Nriagu and Coker, 1978; Krouse, 1989). Hydrogen and oxygen isotopes $\left(\delta^{2} \mathrm{H}\right.$ and $\left.\delta^{18} \mathrm{O}\right)$ have also been applied to mummified tissues and they are discussed further below.

\section{Tissues}

\section{Hair}

The proteins preserved in hair will represent the dietary protein consumed by the individual and can also reflect their physiological condition (Tieszen and Fagre, 1993; Williams et al., 2011). Hair comprises alpha-keratins which are predominantly hydrophobic and thus less likely to be open to degradation (Lubec et al., 1987). When hair is preserved it generally retains the isotope signature of when it formed, and to some degree, hair preservation can be assessed using $\mathrm{C} / \mathrm{N}$ ratios compared to modern hair, which has values of between 2.9-3.8 (O'Connell et al., 2001). Hair preservation is assumed rather than tested routinely as with bone (cf. Wilson et al, 2001) and there remains the possibility of attack by highly adaptive bacteria and fungi (see Macko et al., 1999a for review). For further discussion see Wilson et al. (1999, 2001, 2010) and for a recent review see Thompson et al. (2014).

Since the late 1990's, hair in archaeological settings has been used both as a paleodietary indicator and as a migration indicator. Hair has the potential to give a shortterm signal of diet over the last few months of life, depending on the length of the hair preserved and assuming that the growth rate of the hair is relatively stable. The assumption that hair grows at a steady rate is not straightforward. A mean value of $1 \mathrm{~cm}$ per month for 
humans is often quoted (Saitoh et al., 1969; Randall and Ebling, 1991; Robbins, 2002) but in reality the rate of growth can change for a variety of reasons (e.g. climate, health status, sex, race etc; Macko et al., 1999a). Also, not all hair will be actively growing at the same time with about $85 \%$ of adult hair in active growth at any one time, although the variation in active and resting hair growth patterns is well understood (Schwertl et al. 2003). So called 'growth cycle errors' can lead to misinterpretations of dietary changes within hair samples and Williams et al. (2011) recommend pre-analysis screening for phase identification to improve interpretations. Other authors have tried to ensure they are sampling enough hairs that include hair in the active phase by sampling a large number of strands (e.g. $>20$ per individual; Williams and Katzenberg 2012). Additionally, information on the growth phase and the isotope composition for the nearest time to death can be lost if the hair is cut at the scalp due to the follicle being located under the skin (Williams et al. 2011; Petzke et al. 2010).

The linkage between hair protein and dietary input and/or location of the individual has been demonstrated through analyses of modern populations (O'Connell et al. 2001; Petzke et al. 2005a; Bol et al. 2007; Fraser et al. 2006; Thompson et al. 2010). Hair is approximately $+3.5 \%$ enriched in ${ }^{13} \mathrm{C}$ ( $\mathrm{O}^{\prime}$ Connell et al. 2001) and $1-2 \%$ in ${ }^{34} \mathrm{~S}$ relative to diet (e.g. Nakamura et al. 1982). Due to the high proportion of glycine in collagen (>30\%), which is enriched in ${ }^{13} \mathrm{C}$ compared to other amino acids, the diet-tissue spacing for collagen is higher, $\sim+5 \%$ o for $\delta^{13} \mathrm{C}\left(\mathrm{O}^{\prime}\right.$ Connell et al. 2001). In contrast to carbon, the nitrogen isotope diet-tissue spacing between bone, soft tissues and hair have been found to be roughly equivalent and enriched by +2 to $+3 \%$ in $\delta^{15} \mathrm{~N}$ relative to dietary intake (e.g. O'Connell and Hedges 1999a). However these mean differences have been demonstrated to show a high degree of inter-individual variability (Finucane 2007; O'Connell and Hedges 1999a; Raghavan et al. 2010) which has led researchers to examine proteins at the compound-specific level, to unravel averaged protein isotope composition (Raghavan et al. 2010). Examples of such research are discussed below. Recent work has questioned the diet-body offset for $\delta^{15} \mathrm{~N}$ through experimental studies involving human subjects on controlled diets. O'Connell et al. (2012) measured $\delta^{15} \mathrm{~N}$ in 11 human subjects on isotopically known diets and compared this to their body tissues for a 30 day period. From this they estimated the human diet-keratin offset to be +5.0 to $+5.3 \%$. As previous estimates in the literature used an offset of +2 to $+3 \%$ in $\delta^{15} \mathrm{~N}$ (e.g. Hare et al. 1991), past human diet studies may have overestimated 
amounts of animal protein in the diet. Thus we need to reassess studies that have assumed that vegan diets produce hair $\delta^{15} \mathrm{~N}$ values of around $+7 \%$ ond omnivores around $+10 \%$ o (Macko et al. 1999a) for example. The consumption of marine animals or animals consuming ${ }^{15} \mathrm{~N}$ enriched plants increases the $\delta^{15} \mathrm{~N}_{\text {hair }}$ value towards and beyond $+15 \%$, and even further using O'Connell et al. (2012) findings. The addition of $\delta^{13} \mathrm{C}$ helps us to elucidate further as pure $C_{3}$ feeders have hair $\delta^{13} \mathrm{C}$ values around $-20 \%$ or lower, whilst pure $C_{4}$ feeders have hair $\delta^{13} \mathrm{C}$ values of approximately $-12 \%$ and above (Sponheimer et al. 2003). In terms of $\delta^{13} \mathrm{C}$, hair keratin is enriched by +1 to $+2 \%$ relative to dietary intake and reflects the relative amounts of $C_{3}$ and $C_{4}$ dietary plants and fish intake. $\delta^{13} \mathrm{C}$ values of around -12 to $-14 \%$ (therefore -14 to $-16 \%$ o dietary input), are typical of a predominantly $C_{4}$-based plant diets and may include $\mathrm{C}_{4}$-plants, $\mathrm{C}_{4}$-plant eating animals and marine fish.

The response lag between dietary and location changes and the protein turnover and subsequent preservation in hair also needs to be considered. Although hair may grow on average at $1 \mathrm{~cm}$ per month, it may take substantially longer for the body to assimilate the protein and translate this into the keratin. The hair may register the changes in diet and location very quickly (as soon as 6-12 days: e.g. Nakamura et al., 1982), however other studies have suggested that dietary changes can be seen in hair $\delta^{13} \mathrm{C}$ and $\delta^{15} \mathrm{~N}$ values after about 4 weeks (Huelsemann et al., 2009; Petzke and Lemke, 2009). The time it takes the total body protein pool to equilibrate with a change in diet is not fully understood but will be considerably longer than the initial few days because the body will continually draw on the body's protein pool for daily synthesis. Hence this protein pool acts as a reservoir that may take months to fully equilibrate with a change in diet (O'Connell and Hedges 1999b). A study of $\delta^{2} \mathrm{H}$ and $\delta^{18} \mathrm{O}$ values in hair from modern humans moving to an area with distinguishable water isotope values showed a 95\% equilibration of hair protein within 3 months (Ehleringer et al. 2008). A similar lag was found for $\delta^{15} \mathrm{~N}$ values in hair $\left(\mathrm{O}^{\prime}\right.$ Connell and Hedges 1999b) with equilibration taking longer for $\delta^{13} \mathrm{C}$ (McCullagh et al. 2005). O'Connell and Hedges (1999b) found that complete equilibration may take up to a year but that it was highly dependent on physiological state. Generally, it is thought that the hair does not equilibrate fully for several months and maybe faster for $\delta^{15} \mathrm{~N}$ than $\delta^{13} \mathrm{C}$ (Huelsemann et al., 2009). 


\section{Nails}

Like hair, nails grow incrementally ( 0.10-0.12 mm per day; Zaias 1980) and thus have the potential to provide information on diet and environment in the months prior to death. As with hair keratin, nail keratin also reflects an individual's diet and location in the months before death (e.g. Tieszen et al. 1983; O'Connell et al. 2001; Fraser et al. 2006; Buchardt et al. 2007; Williams and Katzenberg 2012). $\delta^{13} \mathrm{C}$ and $\delta^{15} \mathrm{~N}$ in nails have been shown to strongly correlated to hair from the same individuals and thus can preserve similar changes (Williams and Katzenberg 2012; Sharp et al. 2003; Buchardt et al. 2007). Fraser et al. (2006) found that when comparing hair and nail isotope data $\left(\delta^{15} \mathrm{~N}\right.$ and $\left.\delta^{18} \mathrm{O}\right)$; there was generally more variability in the nail samples. They attributed this to the faster formation of hair and thus in nails there was more time for the isotopes to fractionate due to other biochemical processes occurring.

\section{Skin/muscle}

The proteins within mummified skin and muscle are less frequently preserved when compared to those within hair and there are only a limited number of available stable isotope studies (White and Schwarcz, 1994; Aufderheide et al. 1994; White et al. 1995, 1999; lacumin et al. 1998; Finucane 2007; Williams 2008; Corr et al. 2009). Modern soft tissue studies, including those relating to forensic applications (see Meier-Augenstein 2010, for review) have demonstrated that skin and muscle will, as with bone, preserve the individual's diet and behaviour as the major protein in the dermis is type I collagen (White and Schwarczz 1994). However, unlike bone which turns over and regenerates on the scale of tens of years, muscle and skin will turnover on the scale of weeks to months and thus represent the short period before death (Gerber and Altman 1960; Tieszen et al. 1983). Skeletal muscle turns over on average every 40-60 days (Moore et al. 2005) and dermal collagen every 2-4 months (Babraj et al. 2005). There is currently no simple method for checking the integrity of skin and muscle samples akin to the accepted $\mathrm{C} / \mathrm{N}$ range for bone collagen, however, many authors use this as a rough indicator. As the amino acid composition differs between bone and muscle protein, there is an isotopic offset between them. In terms of carbon, skin and muscle give similar values and are normally offset to bone by $\sim 2 \%$, although this is dependent on diet (see Hare et al. 1991). Positive offsets in $\delta^{15} \mathrm{~N}$ between skin and muscle versus bone from paired samples were $2.1 \pm 0.5 \%$ and 
$1.6 \pm 0.7 \%$ respectively from late prehistoric-early colonial period Peruvian mummies. However, the authors concede that this could be partly due to physiological stress prior to death or differences in decomposition rates (Finucane 2007). In contrast to hair, relatively little theoretical work has been done of isotope systematic within skin and muscle and clearly there is scope for more work here.

\section{Applications}

\section{Dietary fluctuations and identifying time of death}

As hair grows at $\sim 1 \mathrm{~cm}$ per month, the possibility of detecting short-term changes in diet exists if the hair is long enough and can be shown to be responding at a quick enough rate (see above). Human diets can shift for a variety of reasons (seasonal change, movement to different climate zones, food resource issues etc.) and determining or interpreting the controlling factors can be challenging. A successful example is a study of $\delta^{13} \mathrm{C}$ and $\delta^{15} \mathrm{~N}$ in hair and bone of a group of individuals from the Nasca region of Peru (Webb et al. 2013a). As the site is in the high Andes, the ecological food producing zones change over relatively short distances, meaning that individuals do not have to travel far to move into isotopically distinct areas. It also means that seasonal changes in diet are likely to be more pronounced. $\delta^{18} \mathrm{O}$ of individuals from the same region are highly variable, suggestive of wide scale mobility and/or variable water sources (Webb et al. 2013b). Nasca diet included cultivated plants such as maize, domesticated and wild animals and some marine resources, from which Webb et al. (2013a) constructed a local $\delta^{13} \mathrm{C}$ and $\delta^{15} \mathrm{~N}$ food web. There was considerable variation in $\delta^{13} \mathrm{C}$ and $\delta^{15} \mathrm{~N}$ between 17 individuals analysed and along the hair shafts. $\delta^{13} \mathrm{C}$ from individuals ranged from +0.2 to $+6.9 \%$ ond +0.4 to $+5.0 \%$ o for $\delta^{15} \mathrm{~N}$ and there were differences in $\delta^{13} \mathrm{C}$ and $\delta^{15} \mathrm{~N}$ co-variation along the hair shaft and in the overall amount of isotope change seen. The authors categorised these changes into: 1) stable diets, 2) seasonally-shifting diets, 3) single, discrete changes in diet, and 4) exploitation of multiple production zones, thus demonstrating the variety of origins of people buried at the 2 sites and their dietary resourcefulness.

Knudson et al. (2007) examined $\delta^{13} \mathrm{C}$ and $\delta^{15} \mathrm{~N}$ variations in sequential hair segments from 10 individuals from the Chiribaya polity of southern Peru. Variations in $\delta^{13} \mathrm{C}$ and $\delta^{15} \mathrm{~N}$ along the hair shafts were interpreted as reflecting the individuals' seasonally-controlled 
dietary intake of marine protein and $C_{4}$ plants (predominantly maize). Knudson et al. (2007) observed that the amount of variation differed between the geographical locations of the individuals and included inter and intra variability within and between individuals. The Chiribaya polity consisted of different socioeconomic groups and Knudson et al. (2007) argue that the variation in the isotope ratios between these groups support the notion that they had different dietary regimes. This study also stresses the need to anlayse more than a few individuals if a true picture of variability is to be achieved.

Williams and Katzenberg (2012) analysed hair and nails from late Horizon (1476-1532 AD) mummies preserved on the central coast of Peru. They analysed $\delta^{13} \mathrm{C}$ and $\delta^{15} \mathrm{~N}$ in $1 \mathrm{~cm}$ increments of multiple strands of hair from 45 individuals and nails from 15 individuals (11 individuals had both) to asses monthly dietary changes (and compared them to bone to look at long term seasonal variability). They showed that diet apparently varied from month to month, and presumably did not involve substantial storage of food, as this would result in fairly constant isotope ratios.

Seasonally shifting diets have also been established in East African mummies; Schwarczz and White (2004) found seasonal patterns in food consumption from the hair of X-Group and Christian Nubian mummies. Changes in the consumption of $C_{3}$ and $C_{4}$ plants annually was estimated to be as much as $75 \% \mathrm{C}_{3}$ (wheat and barley) in winter, to $75 \% \mathrm{C}_{4}$ (millet and sorghum) in the summer. As with the above example, this suggests little food storage, except for emergency use.

If the seasonality of food consumption can be established through incremental analysis of hair then the season or time of death can also potentially be assessed from hair. Williams and Katzenberg (2012) attempted to do this and concluded that death rates tended to be slightly higher in the summer months. Their hypotheses for this included the documented higher risk from disease (e.g. cholera and malaria) and the increased possibility of major crop failure. Establishing the timing of death has shown to be difficult as it relies upon knowing the existing seasonal patterns of food consumption (Wilson et al., 2007). Fernández et al. (1999) argued that Aconcagua boy died in the early autumn (April/May) when his hair $\delta^{13} \mathrm{C}$ was relatively low and thus related to a seasonal period of reduced maize consumption. However, Wilson et al. (2007) point out that that his diet was generally $\mathrm{C}_{4}{ }^{-}$ plant rich in the almost 2 years up to his death. 


\section{$C_{3} / C_{4}$ plant consumption}

Studies have focused on the introduction of cultivated $C_{4}$ plants in the diet, linked to wider questions concerning the development of complex societies. On the African continent, focus on $\mathrm{C}_{4}$ plant consumption has included millet and sorghum, and in the New World focus has been on the identification of the beginnings of maize consumption (e.g. Katzenberg et al. 1989; White and Schwartz 1989). Thompson et al. (2008) reviewed the evidence from stable isotope studies of human diet from mummies in Nubia (Sudan). The studies predominantly focus on bone collagen but do include some skin and hair studies (White 1993; White et al. 1999). Together all the tissues suggest that the Nubian diet was richer in $C_{4}$ plants than the northern Nile Valley in Egypt, an observation that has been widely made in other studies (Dupras and Schwarczz 2001; Dupras et al. 2001; lacumin et al. 1996; Thompson et al. 2005). White and Schwartz (1994) were able to sample soft tissues and skin from a number of Nubian mummies from Wadi Halfa on the Egyptian border spanning the X-Group Period (350-550 AD) to the Christian period (500-1400 AD). They revealed that although $C_{3}$ plants dominated consumption, both through time and on an annual basis, there were periods of significant $\mathrm{C}_{4}$ consumption during the $\mathrm{X}$-Group Period, corresponding to low levels of the River Nile and periods of political unrest. Analyses along the hair shaft revealed seasonal fluctuations in the $C_{3} / C_{4}$ balance as far back as the X-Group period, suggesting some form of crop rotation, which still carries on today.

The Sudan is one of the driest regions on Earth with mean annual precipitation $\sim 5 \mathrm{~mm}$ per annum and hence $\mathrm{C}_{4}$ adapted plants are common and may form crop staples to the diet (e.g. $C_{4}$ millet, sorghum) in combination with $C_{3}$ plants grown in winter months (wheat and barley). The same is not true for Egypt, which until the Roman period was dominated by wheat and barley, with only a few sites indicating much $\mathrm{C}_{4}$ consumption, and this may be due to $C_{4}$ plant based animal fodder rather than direct human consumption (Dupras et al. 2001; Dupras and Tocheri 2007).

The human hair studies from Nubia collectively suggest that the balance of $C_{3}$ and $C_{4}$ plants in individuals' diet fluctuates seasonally with agricultural practises (Schwarczz and White 2004; White 1993; White and Schwarczz 1994). Whereas in ancient Egypt, $\delta^{13} \mathrm{C}$ evidence from predynastic period ( $5500 \mathrm{BP}$ ) to Byzantine period (1500 BP) individuals shows remarkably constant values suggesting a restricted diet and little significant changes in food sources through time (Touzeau et al. 2014). In ancient Egypt this is also true when 
human hair $\delta^{13} \mathrm{C}$ from individuals from the Nile valley and from individuals residing away from the river are also compared (Touzeau et al. 2014).

\section{Marine diet adaptations}

The discovery of 18 naturally mummified individuals from the Early Intermediate period from the coast of northern Chile provided Aufderheide et al. (1994) with an opportunity to assess marine food consumption. The mummies concerned were from the Alto Ramirez cultural period, believed to be the first migrants to settle in lowland Chile from the highlands, and thus the authors were interested in assessing how quickly they adapted to living at the coast. Aufderheide et al. (1994) analysed bone, hair and muscle tissue from 11 individuals. The collagen from the bone samples was degraded and also, in terms of $\delta^{13} \mathrm{C}$, the difference between muscle and muscle with lipid extracted values was $2.3 \%$, far greater than is seen in modern muscle tissues and hence they concluded that the muscle tissue was also degraded. The hair keratin $\delta^{13} \mathrm{C}$ values $(-12.3$ to $-15.6 \%$ ) were relatively high, suggesting a diet rich in marine foods and/or C4 plants. Similarly, high hair $\delta^{15} \mathrm{~N}$ and $\delta^{34} \mathrm{~S}$ values ( +21.9 to $+27.0 \%$ and +15.6 to $+19.0 \%$ respectively) strongly suggest a high degree of marine food consumption and thus a high degree of coastal adaptation.

In general, however, $\delta^{15} \mathrm{~N}$ from mummies in arid regions have proved to be difficult to use as marine diet indicators for several reasons. Plant $\delta^{15} \mathrm{~N}$ has been shown to linearly correlate with rainfall amount (Heaton et al. 1986; Sealy et al. 1987; Schwarczz et al. 1999). Ammonia evaporation from the soil results in ${ }^{15} \mathrm{~N}$ enriched soil and consequently the base of the food chain becomes enriched in ${ }^{15} \mathrm{~N}$ (Schwarczz et al. 1999), this causes some plants to have enriched values and as a consequence herbivores can have collagen $\delta^{15} \mathrm{~N}$ in excess of $+13 \%$ o (Touzeau et al. 2014). In such circumstances sulphur and compound specific isotopes can help to elucidate on the significance of marine resources in arid areas (see below).

\section{Amount of animal protein}

$\delta^{13} \mathrm{C}$ in hair has also been used to estimate the amount of animal protein consumed using mass balance calculations (Touzeau et al. 2014). Using best estimates for average animal and plant proteins available to them, Touzeau et al. (2014) estimated a value of $~ 30 \%$ animal protein in the diet for ancient Egyptians. Considering with modern Europeans this value is closer to $50 \%$, ancient Egyptians consumed significantly less animal protein than 
today. Touzeau et al. (2014) also found that average $\delta^{15} \mathrm{~N}$ in Egyptian mummy hair were higher than for modern Europeans, but this could have a variety of reasons, such as aridity as discussed above, but also nutritional stress and illness can elevate animal $\delta^{15} \mathrm{~N}$ tissue values (Katzenberg and Lovell 1999).

\section{Migration}

Many studies have utilised the fact that hair grows incrementally and thus can be used to infer seasonal changes in diet and also location. White et al. (2009) for example, analysed $\delta^{13} \mathrm{C}$ and $\delta^{15} \mathrm{~N}$ along the hair shaft of 7 individuals preserved from Pacatnamu, Peru from the Moche (ca. 450-750 AD) and Lambayeque periods (ca. 900-1100 AD). They found that the range of isotope values with the hair of an individual (up to 2.2 and $2.3 \%$ ofor $\delta^{13} \mathrm{C}$ and $\delta^{15} \mathrm{~N}$ ) exceeded the difference in $\delta^{13} \mathrm{C}$ and $\delta^{15} \mathrm{~N}$ in bone between individuals from the different time periods. This serves to illustrate how dietary variations over short time periods can be lost in bone. They concluded that the variation was more likely to be due to the individuals travelling in the landscape and eating a varied diet rather than seasonal variations from sedentary individuals, possibly due to the need to relocate because of environmental stresses on food resources.

\section{Sacrificial Practices}

The analysis of hair samples from sacrifice victims has the potential to uncover how victims were treated prior to their death. It has been observed that post-selection, victims of sacrifice are often treated differently in the months and weeks leading up to their death, and also may have been moved a considerable distance (Fernández et al. 1999; also see below). Turner et al. (2013) tested the hypothesis that victims would have had a controlled diet prior to death by comparing $\delta^{13} \mathrm{C}$ and $\delta^{15} \mathrm{~N}$ in hair to $\delta^{13} \mathrm{C}$ and $\delta^{15} \mathrm{~N}$ in bone from individuals identified as victims of ritual sacrifice. The individuals came from Chotuna-Huaca de los Sacrificios, Lambayeque, Peru; a coastal province on the margins of central Inca society. Hence, there is the possibility that Inca rituals were not as closely adhered to as in the centre of Peru. As bone collagen will represent a long-term averaged diet and hair will reflect the last few months/weeks prior to death, differences between the two proxies within individuals may suggest a significant change in location and/or diet. In this case $\delta^{13} \mathrm{C}$ and $\delta^{15} \mathrm{~N}$ from the bone and hair were very similar (after correcting for diet-tissue spacing) 
and indicative of a typical coastal diet from that period. This also suggests that these victims were likely to be local to the site. Elsewhere, differences have been seen between longterm diet and short-term diet in sacrifice victims. Wilson et al. (2007) examined the hair of four frozen child mummies from high altitude Inca ritual sites. The length of the preserved hair allowed Wilson et al. (2007) to reconstruct the children's diets up to around 2 years prior to their deaths. A variety of changes to diet were evident, including in one individual a significant increase in protein around 1 year prior to death, concurrent with an increase in $\delta^{13} \mathrm{C}$ suggested to show more maize. As maize was an elite food, presumably this individual had an increase in status, perhaps in preparation for sacrifice. Panzer et al. (2014) used a variety of techniques, including stable isotope and palaeopathology to strongly suggest a coastal Peruvian origin. The individual had massive skull trauma and thus it is postulated that she may have been a ritual killing victim. Her hair $\delta^{13} \mathrm{C}$ and $\delta^{15} \mathrm{~N}$ indicate a high consumption of marine protein, which declines in the 2 months before her death (Table 1 ).

\section{Individual mummies}

In several cases where lone individuals have been found in a preserved mummified state (e.g. emerging from beneath glacier ice, or in hyper arid regions), isotope data can reveal the history of the individual in terms of their diet and whereabouts in the months leading up to death. Corr et al. (2009) used compound specific isotope analysis on an individual body found emerging from a retreating glacier in British Columbia, Canada, in order to determine the origin of the individual. They analysed both bone and skin to determine if the individual had moved location prior to death and this is discussed further below. Knudson et al. (2012) examined a range of tissues from a lone adult male found in the Atacama Desert, Chile. The $\delta^{13} \mathrm{C}$ and $\delta^{15} \mathrm{~N}$ of his hair indicated that he was moving between the coast and inland during the final 20 months of his life. They interpret high $\delta^{15} \mathrm{~N}$ values $6-8$ months before death as a high marine food diet and thus coastal dwelling, compared to terrestrial dwelling 8-12 months prior to death.

Perhaps the most studied individual mummy of recent time is the Neolithic Iceman 'Otzi' found in the Austrian Alps in 1999 (Macko et al. 1999b). Farming was already established in Europe and thus potentially he may have had access to a wide range of meat and cereal crops. Previous work on his dental wear suggests a largely herbivorous diet (Hoepfel et al. 1992). Hair from a goat pelt, found with the body, was also analysed and 
when compared to the ice man's hair was within 1\%o $\left(\delta^{15} \mathrm{~N}\right)$; if the ice man was consuming meat from animals like goat then his hair values would be $\sim 3 \%$ o higher in $\delta^{15} \mathrm{~N}$, but this is not the case. Instead his hair $\delta^{15} \mathrm{~N}$ values were similar to samples taken from modern vegetarians and the $\delta^{13} \mathrm{C}$ values were relatively low and suggestive of $C_{3}$ plant consumption.

Fernández et al. (1999) analysed $\delta^{13} \mathrm{C}, \delta^{15} \mathrm{~N}$ and $\delta^{34} \mathrm{~S}$ in bone and hair from a sacrificial Inca mummified body from the Argentinean Andes to try and discover where the individual had travelled from as there was no other evidence from the body or grave goods. If the individual was local, a terrestrial diet is likely, but any evidence of marine food would suggest proximity to the Pacific coast. The results are discussed below with the sulphur examples.

\section{Advances in isotope techniques}

\section{Sulphur}

Sulphur isotope ratios are increasingly being used as to distinguish between marine and terrestrial diets (see Richards et al., 2003 for review) and can be useful when $\delta^{15} \mathrm{~N}$ is complicated by aridity or nutritional stress and where the sulphur isotope systematics of a region are clear and defined. Touzeau et al. (2014) defined the range of local $\delta^{34} S$ for freshwater fish from the Nile using mummified specimens. These fish, mostly Nile Perch, had $\delta^{34} \mathrm{~S}$ values of +7 to $+12 \%$ and as there is only minimal fractionation between diet and consumer, humans consuming a lot of fish should have hair $\delta^{34} S$ values around this level. This was seen in the hair of mummies from the Coptic period, but was not matched by elevated $\delta^{15} \mathrm{~N}$ and hence Touzeau et al. (2014) conclude that they may have been eating freshwater products lower down the food chain than perch (e.g. crayfish).

In contrast, a marine diet was indicated by hair $\delta^{34} S$ between +15.6 and $+19.0 \%$ o from 11 mummies from the early intermediate period from the coast of northern Chile (Aufderheide et al. 1994). Based on measurements from modern marine foods, a diet entirely composed of such could be expected to have hair $\delta^{34} S$ values of +18 to $+19 \%$ o (Krouse and Herbert 1988; Aufderheide al. 1994). On an individual mummy from the Argentinean Andes, Fernández et al. (1999) analysed $\delta^{13} \mathrm{C}, \delta^{15} \mathrm{~N}$ and $\delta^{34} \mathrm{~S}$ in bone and hair to try to determine place of origin. In this case the bone $\delta^{13} \mathrm{C}$ and $\delta^{15} \mathrm{~N}$ could not be used to distinguish between a continental high $\mathrm{C}_{4}$ plant intake and a marine input to diet or a 
combination of both. The addition of $\delta^{34} S$ allowed these inputs to be discriminated. Sequential $\delta^{13} \mathrm{C}$ in the individual's hair were suggestive of a seasonally variable continental diet at least up to a year and a half before death. The addition of $\delta^{34} S$ values at the root and tip of the hair gave values of +9.4 and $+10.9 \%$ respectively; consistent with some marine input.

As $\delta^{34} S$ will also vary with geological substrate it can also be used as a geo-location tool. Wilson et al. (2007) found that the hair $\delta^{34} S$ values from three Inca child mummies coincided 6 months before their deaths. As the victims were sacrificial, Wilson et al. (2007) interpreted this as the individuals being brought together to prepare them for sacrifice at the same location.

\section{Hydrogen \& Oxygen}

As carbon, nitrogen and sulphur isotope ratios preserved in body tissues may reflect the dietary intake of an individual, hydrogen and oxygen isotopes have the potential to reflect their water intake and thus can potentially be a proxy for location and migration (Ehleringer et al. 2008; O'Brien and Wooller 2007). Sharp et al. (2003) using a study of both modern and archaeological hair concluded that the balance of food/water inputs to hair $\delta^{2} \mathrm{H}$ was about a third from drinking water and the rest from food. Hence if food sources are predominantly local and local meteoric water composition is understood, the $\delta^{2} \mathrm{H}$ of hair can represent local meteoric water composition (Bowen et al. 2009). Fraser and Meier-Augenstein (2007) developed a correlation equation to convert measured hair $\delta^{2} H$ values to meteoric water $\delta^{2} \mathrm{H}$ values so information could be established on potential areas of habitation of the individuals concerned. This application has been successful in helping to identify victims in modern homicide cases (Fraser et al. 2006; Fraser and Meier-Augenstein 2007; MeierAugenstein 2010). One major limitation to the application of $\delta D$ in hair is that it is highly exchangeable, even after synthesis (DeNiro and Epstein 1981), and as a result isotope analysis is technically more difficult and exchangeable hydrogen needs to be taken into account (Wassenaar and Hobson 2002; Bowen et al. 2005). Hence studies have generally separated and analysed non-exchangeable $\delta^{2} \mathrm{H}$ (Ehleringer et al. 2008).

As water also enters the body through the food we eat, there is also the possibility that $\delta^{2} \mathrm{H}$ and $\delta^{18} \mathrm{O}$ can serve as a paleodiet proxy (Thompson et al. 2010; Bowen et al. 2009). Bowen et al. (2009) analysed hair from modern Inuit groups and found they had unusually 
high hair $\delta^{2} \mathrm{H}$ and $\delta^{18} \mathrm{O}$, more suggestive of tropical meteoric water values and that their hair $\delta^{2} \mathrm{H}$ and $\delta^{18} \mathrm{O}$ deviate from the observed correlation between these isotopes seen in modern American individuals. The Inuit individuals also had very high tissue $\delta^{15} \mathrm{~N}$ reflecting their marine protein-rich diet (including marine mammals). Bowen et al. (2009) modelled the expected hair $\delta^{2} \mathrm{H}$ and $\delta^{18} \mathrm{O}$ for the individuals using contemporary marine fish $\delta^{2} \mathrm{H}$ and $\delta^{18} \mathrm{O}$ and found that there was a good fit to the data. As dietary versus water contributions to hair amino acid are more significant for hydrogen (Bowen et al. 2009), high $\delta^{2} \mathrm{H}$ in some individuals may be used to identify a high intake of marine foods.

Sharp et al. (2003) measured $\delta^{2} \mathrm{H}, \delta^{13} \mathrm{C}$ and $\delta^{15} \mathrm{~N}$ along the hair shaft of an Inca mummy (Argentina; Fernández et al. 1999) and saw corresponding sinusoidal patterns in both the $\delta^{2} \mathrm{H}$ and $\delta^{13} \mathrm{C}$. They interpreted these as seasonal patterns with low $\delta^{2} \mathrm{H}$ corresponding to winter months (consistent with meteoric water) and higher $\delta^{2} \mathrm{H}$ in the summer with increased evaporation. The correspondingly higher $\delta^{13} \mathrm{C}$ in summer were linked to increased consumption of $C_{4}$ plants, most likely maize. Wilson et al. (2007) extended the hair $\delta^{2} \mathrm{H}$ and $\delta^{18} \mathrm{O}$ study of Inca child sacrifice victims and suggested that the data indicated the 4 individuals were from a highland location, and thus likely to be of low status.

$\delta^{2} \mathrm{H}$ and $\delta^{18} \mathrm{O}$ applications to archaeological samples are limited to a few studies and have focused predominantly on bone collagen (see Reynard and Hedges 2008 for review). However, the potential for investigating palaeodiet and location remains.

\section{Compound specific isotope analysis}

In the last 10 years, the use of compound specific isotope analysis has expanded the range of questions that isotopes can answer both from bone and from soft tissues. Rather than analysing bulk proteins, individual amino acids are identified, separated and analysed to give a much more specific understanding of dietary routing (see Petzke et al. 2010 for review on hair). Whereas non-essential amino acids can be synthesized by humans, essential amino acids cannot and must be provided directly from the diet (Fogel and Tuross 2003). Thus the analysis of individual amino acids provides a direct tracer for dietary intake. This becomes useful when faced with the problem of elevated $\delta^{15} \mathrm{~N}$ due to water stress in arid climates ( $<400 \mathrm{~mm}$ of rainfall per annum) where $\delta^{15} \mathrm{~N}$ from marine animals and herbivores are 
indistinguishable (Heaton et al. 1986). In addition, the overlap in $\delta^{13} \mathrm{C}$ between marine animals and $\mathrm{C}_{4}$ plants in arid regions may also add to the difficulty in distinguishing marine and terrestrial diets. Corr et al. (2005) demonstrated that consumers of marine protein had relative ${ }^{13} \mathrm{C}$-enrichment in the non-essential amino acid glycine in their bone collagen when compared to $C_{4}$ terrestrial consumers, but this was not the case with the essential amino acid phenylalanine. The theory being that the two amino acids have different metabolic pathways and thus preserve inputs from different parts of the diet. There is a high demand for glycine in the body that cannot be met through diet alone and thus much of it is biosynthesised de novo. As most of the glycine in bone collagen derives from glucose, it will reflect the carbohydrate part of the diet and as marine ecosystems have comparatively more trophic levels there is more fractionation than in terrestrial systems (Corr et al. 2005).

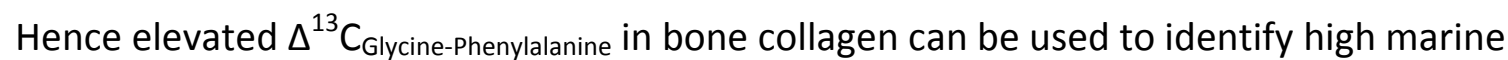
protein consumers. Corr et al. (2009) extended this discovery to mummified soft tissues and compared 8 of the amino acids within the bone and skin of an individual found at $1600 \mathrm{~m}, 80$ $\mathrm{km}$ inland in British Columbia to determine if the individual had moved location prior to death. They compared the long term diet as reflected in the bone collagen values with the last few months of life as represented within the skin tissue. They used $\Delta^{13} \mathrm{C}_{\mathrm{Glycine}}$-Phenylalanine to examine the degree of marine resource consumption. The bone values suggested that this individual was a coastal dweller, consuming a significant proportion of marine food, and by contrast the values from the skin samples were significantly lower and suggested that the individual had been inland for a few months prior to and up to his death and was consuming more terrestrial/freshwater foods. In order to do this, Corr et al. (2009) used a reference set of terrestrial (deer and dog) and marine (salmon and sea lion) animals from an earlier regional archaeological site from which they analysed carbon isotopes which showed that the amino acids in general were higher in $\delta^{13} \mathrm{C}$ in the marine animals compared to the terrestrial animals. For example $\Delta{ }^{13} \mathrm{C}_{\text {Glycine-Phenylalanine }}$ were $+6.6 \pm 0.6 \%$ for the terrestrial animals and $+15.0 \pm 2.1 \%$ o for the marine animals. Isotopic analysis of his hair also suggested a switch to terrestrial foods (Richards et al. 2007). This study also shows the value of analysing skin in addition to bone to elucidate on the life history of an individual.

Several studies detailing compound specific isotope analysis of amino acids in hair keratin have been published (McCullagh et al. 2005; Petzke et al. 2005a\&b; Petzke et al. 2006; Petzke and Lemke 2009; Smith et al. 2009) with one archaeological application to date 
(Raghavan et al. 2010). Raghavan et al. (2010) attempted to address the question of the isotope relationship between hair and bone at the amino acid level. They took hair and bone samples from $16^{\text {th }}$ and $17^{\text {th }}$ century mummified humans from Uummannaq, Greenland and analysed $\delta^{13} \mathrm{C}$ from a number of corresponding hair and bone amino acids from 6 individuals. They were able to separate and analyse 15/18 amino acids from bone and 13/18 for hair and refine the technique to allow them to analyse very small hair samples, and thus segmented hair samples. Thus, this offers a starting point for future compound-specific isotope studies of hair when bone maybe unavailable.

\section{Conclusions}

The limited preservation and availability of mummified soft tissues make the application of stable isotope analyses to answer archaeological questions rare and this is especially true for skin and muscle. The analysis of mummified hair is more common and the examples outline here illustrate how it has been especially successful with questions that address the elucidation of short term diet. Where such tissues are available they can answer questions that bulk, bone collagen analyses cannot and thus they are an expanding field in bioarchaeology. Advances in on-line compound-specific mass-spectrometry during the last 10 years have allowed the analysis of individual amino acids within soft tissues and there has also been a growth in a wider variety of isotopes beyond carbon and nitrogen (oxygen, hydrogen and sulphur).

\section{Acknowledgments}

Thanks are expressed to my colleagues who have worked with me on mummified tissues over the years including Ryan Metcalfe, Jenefer Cockitt, Andrew Chamberlain, Walaa Baker, Hannah O'Regan, Sarah Elton, Carolyn Chenery, Jane Evans, Silvia Gonzalez and Nick Feldstead. Melanie Leng and two anonymous reviewers are thanked for their constructive comments.

\section{Table 1}

Summary stable isotope data from published soft tissue and hair samples from mummified human remains. 


\section{References}

Aufderheide, A. C. 2003. The Scientific Study of Mummified Human Remains. Cambridge: Cambridge University Press.

Aufderheide, A.C., Kelley, M.A., Rivera, M., Gray, L., Tieszen, L.L., Iversen, E., Krouse, H.R. and Carevic, A. 1994. Contributions of Chemical Dietary Reconstruction to the Assessment of Adaptation by Ancient Highland Immigrants (Alto Ramirez) to Coastal Conditions at Pisagua, North Chile. Journal of Archaeological Science 21, 515-524.

Babraj J.A., Cuthbertson D.J., Smith K., Langberg H., Miller B., Krogsgaard M.R., Kjaer M., Rennie M.J. 2005. Collagen synthesis in human musculoskeletal tissues and skin. American Journal of Physiology Endocrinology and Metabolism 289, 864-869.

Beaumont, J., Geber, J., Powers, N., Wilson, A.S., Lee-Thorp, J. and Montgomery, J. 2013. Victims and survivors: stable isotopes used to identify migrants from the Great Irish Famine to 19th Century London. American Journal of Physical Anthropology 150, 87-98.

Bol, R., Marsh, J. and Heaton, T.H.E. 2007. Multiple stable isotope $\left({ }^{18} \mathrm{O},{ }^{13} \mathrm{C},{ }^{15} \mathrm{~N}\right.$ and $\left.{ }^{34} \mathrm{~S}\right)$ analysis of human hair to identify the recent migrants in a rural community in SW England. Rapid Communications in Mass Spectrometry 21, 2951-2954.

Bowen, G.J., Chesson, L., Nielson, K., Cerling, T.E. and Ehleringer, J.R. 2005. Treatment methods for the determination of $\mathrm{d} 2 \mathrm{H}$ and $\mathrm{d} 180$ of hair keratin by continuous-flow isotope-ratio mass spectrometry. Rapid Communications in Mass Spectrometry 19, 2371-2378.

Bowen G.J., Ehleringer J.R., Chesson L.A., Thompson, A.H., Podlesak, D.W. and Cerling, T.E. 2009. Dietary and physiological controls on the hydrogen and oxygen isotope ratios of hair from mid$20^{\text {th }}$ century indigenous populations. American Journal of Physical Anthropology 139, 494-504.

Britton, K., Knecht, R., Nehlich, O., Hillerdal, C., Davis, R.S. and Richards, M.P. 2013. Maritime adaptations and dietary variation in prehistoric Western Alaska: Stable isotope analysis of permafrost-preserved human hair. American Journal of Physical Anthropology 151, 448-461.

Buchardt B., Bunch V. and Helin P. 2007. Fingernails and diet: stable isotope signatures of a marine hunting community from modern Uummannaq, North Greenland. Chemical Geology 244, 316-329.

Corr, L.T., Richards, M.P., Grier, C., Mackie, A., Beattie, O. and Evershed, R.P. 2009. Probing dietary change of the Kwädąy Dän Ts'ìnchį individual, an ancient glacier body from British Columbia: II. Deconvoluting whole skin and bone collagen $\delta^{13} \mathrm{C}$ values via carbon isotope analysis of individual amino acids. Journal of Archaeological Science 36, 12-18.

Corr, L.T., Sealy, J.C., Horton, M.C. and Evershed, R.P. 2005. A novel marine dietary indicator utilising compound-specific bone collagen amino acid $\delta^{13} \mathrm{C}$ values of ancient humans. Journal of Archaeological Science 32, 321-330.

David, R. A. 1982. The Ancient Egyptians - Religious Beliefs and Practises. London: Routledge \& Kegan Paul Ltd. 
David, R. A. (ed.) 1986. Science in Egyptology: proceedings of the Science in Egyptology Symposia, pp. 8790. Manchester: Manchester University Press.

Davies, E. 2011. Mummy mania. Chemistry World 8 (2), February 2011, 48-51.

DeNiro M.J. and Epstein S. 1981. Hydrogen isotope ratios of mouse tissues are influenced by a variety of factors other than diet. Science 214, 1374-1375.

Dupras, T.L. and Schwarczz, H.P. 2001. Strangers in a strange land: stable isotope evidence for human migration in the Dakhleh Oasis, Egypt. Journal of Archaeological Science 28, 1199.

Dupras, T.L., Schwarczz, H.P. and Fairgrieve S.I. 2001. Infant feeding and weaning practices in Roman Egypt. American Journal of Physical Anthropology 115, 204-211.

Dupras, T.L. and Tocheri, M.W. 2007. Reconstructing infant weaning histories at Roman period Kellis, Egypt using stable isotope analysis of dentition. American Journal of Physical Anthropology 134, 63-74.

Ehleringer J.R., Bowen G.J., Chesson L.A., West, A.G., Podlesak, D.W. and Cerling, T.E. 2008. Hydrogen and oxygen isotope ratios in human hair are related to geography. Proceedings of the National Academy of Sciences 10, 2788-2793.

Fernández, J. Panarello, H.O. and Schöbinger, J. 1999. The Inka Mummy from Mount Aconcagua: Decoding the geographic origins of the "Messenger to the Deities" by means of stable carbon, nitrogen, and sulfur isotope analysis. Geoarchaeology 14, 27-46.

Finucane, B.C. 2007. Mummies, maize, and manure: multi-tissue stable isotope analysis of late prehistoric human remains from the Ayacucho Valley, Perú. Journal of Archaeological Science 34, 2115-2124.

Fogel, M.L. and Tuross, N. 2003. Extending the limits of paleodietary studies of humans with compound specific carbon isotope analysis of amino acids. Journal of Archaeological Science 30, 535-545.

Fraser, I. and Meier-Augenstein, W. 2007. Stable ${ }^{2} \mathrm{H}$ isotope analysis of human hair and nails can aid forensic human identification. Rapid Communications in Mass Spectrometry 21, 3279-3285.

Fraser, I., Meier-Augenstein, W. and Kalin, R.M. 2006. The role of stable isotopes in human identification: a longitudinal study into the variability of isotopic signals in human hair and nails. Rapid Communications in Mass Spectrometry 20, 1109-1116.

Fuller, B. T., Fuller, J. L., Sage, N. E., Harris, D. A., O'Connell, T. C. and Hedges, R. E. M. 2005. Nitrogen balance and $\delta^{15} \mathrm{~N}$ : why you're not what you eat during nutritional stress. Rapid Communications in Mass Spectrometry 19, 2497-2506.

Gerber, G. And Altman, K.I. 1960. Studies on the metabolism of tissue proteins. 1. Turnover of collagen labeled with prolineTJ-C ${ }^{14}$ in young rats. Journal of Biological Chemistry 235, 2653-2656.

Hare, P.E., Fogel, M.L., Stafford, T.W., Mitchell, A.D. and Hoering, T.C. 1991. The isotopic composition of carbon and nitrogen in individual amino acids isolated from modern and fossil proteins. Journal of Archaeological Science 18, 277-292.

Heaton, T.H.E., Vogel, J.C., von la Chevallerie, G. and Collett, G., 1986. Climatic influence on the isotopic composition of bone nitrogen. Nature 322, 822-823. 
Hedges, R., Clement, J., Thomas, C. and O'Connell, T. 2007. Collagen turnover in the adult femoral mid-shaft: Modeled from anthropogenic radiocarbon tracer measurements. American Journal of Physical Anthopology 133, 808-816.

Hill, P.A. and Orth, M. 1998. Bone remodelling. British Journal of Orthodontics 25(2), 101-107.

Hoepfel, F., Platzer, W., and Spindler, K. 1992. Der Mann im Eis. Eigenverlag der Universitaet, Innsbruck, Austria.

Horn, P., Hölzl, S., Rummel, S., Åberg, G., Schiegl, S., Biermann, D., Struck, U. and Rossmann, A. 2009, pp. 173-192 in Reindel, M. and Wagner, G.A. (eds.) New Technologies for Archaeology: Multidisciplinary Investigations in Palpa and Nasca, Peru. Berlin: Springer.

Huelsemann, F., Flenker, U., Koehler, K. and Schaenzer, W. 2009. Effect of a controlled dietary change on carbon and nitrogen stable isotope ratios of human hair. Rapid Communications in Mass Spectrometry 23, 2448-2454.

lacumin, P., Bocherens, H., Chaix, L. and Mariotti,A., 1998. Stable carbon and nitrogen isotopes as dietary indicators of ancient Nubian populations (Northern Sudan). Journal of Archaeological Science 25: 293-301.

lacumin, P., Bocherens, H., Mariotti, A. and Longinelli, A., 1996. An isotopic palaeoenvironmental study of human skeletal remains from the Nile Valley. Palaeogeography Palaeoclimatology Palaeoecology 126, 15-30.

Katzenberg, M. A., Schwarczz, H.P., Knyf, M. and Melbye, F. J. 1989. Stable isotope evidence for maize horticulture and paleodiet in southern Ontario, Canada. American Antiquity 60, 335-350.

Katzenberg, M. A. and Lovell N.C. 1999. Stable isotope variation in pathological bone. International Journal of Osteoarchaeology 9, 316-324.

Knudson, K.J., Aufderheide, A.E. Buikstra, J.E. 2007. Seasonality and paleodiet in the Chiribaya polity of southern Peru. Journal of Archaeological Science 34, 451-462.

Knudson, K.J., Pestle, W.J., Torres-Rouff, C. and Pimentel, G. 2012. Assessing the Life History of an Andean Traveler through Biogeochemistry: Stable and Radiogenic Isotope Analyses of Archaeological Human Remains from Northern Chile. International Journal of Osteoarchaeology 22, 435-451.

Krouse, H.R. and Herbert, M.K. 1988. Sulphur and carbon isotope studies of food webs, pp. 315-322. In Kennedy, B.W. and LeMoine, G.M. (eds.), Diet and subsistence: Current archaeological perspectives. Calgary: University of Calgary Archaeological Association.

Krouse, H. R. 1989. Sulfur Isotope Studies of the Pedosphere and Biosphere, pp.424-444. In Rundel, P.W., Ehleringer, J.R. and Nagy, K.A. (eds.), Stable Isotopes in Ecological Research. Springer-Verlag, New York.

Lubec, G., Nauer, G., Seifert, K., Strouhal, E., Portecler, H., Szilvassy, I. and Teschler, M. 1987. Structural stability of hair over 3000 years. Journal of Archaeological Science 14, 113-120. 
McCullagh, J.S.O., Tripp, J.A. and Hedges, R.E.M. 2005. Carbon isotope analysis of bulk keratin and single amino acids from British and North American hair. Rapid Communications in Mass Spectrometry 193, 3227-3231.

Macko, S.A., Engel, M.H., Andrusevich,V., Lubec, G., O'Connell, T.C. and Hedges, R.E.M. 1999a. Documenting the diet in ancient human populations through stable isotope analysis of hair. Philosophical Transactions of the Royal Society London B 354, 65-76.

Macko, S.A., Lubec, G., Teschler-Nicola, M., Andrusevich, V. and Engel, M.H. 1999b. The Ice Man's diet reflected by the stable nitrogen and carbon isotopic composition of his hair. Federation of American Societies for Experimental Biology Journal 13, 559-562.

Meier-Augenstein, W. 2010. Stable Isotope Forensics. Chichester, UK: John Wiley \& Sons, Inc.

Metcalfe, R. 2008. The Tutankhamouse Experiment: Investigating Tissue Changes during Mummification, pp 81-88. In Gashe, V. and Finch, J. (eds), Current research in Egyptology. Rutherford Press, Bolton.

Moore, D.R., Phillips, S.M., Babraj, J.A., Smith, K. and Rennie, M.J. 2005. Myofibrillar and collagen protein synthesis in human skeletal muscle in young men after maximal shortening and lengthening contractions. American Journal of Physiology - Endocrinology and Metabolism 288, 1153-1159.

Nakamura, K., Schoeller, D.A., Winkler, F.J. and Schmidt, H.L. 1982. Geographic variations in the carbon isotope composition of the human diet and human hair in contemporary man. Biomedical Mass Spectrometry 9, 390-394.

Nehlich, O., Boric, D., Stefanovic, S. and Richards, M.P. 2010. Sulphur isotope evidence for freshwater fish consumption: A case study from the Danube Gorges, SE Europe. Journal of Archaeological Science 37, 1131-1139.

Nriagu, J.O. and Coker, R.D. 1978. Isotopic composition of sulfur in precipitation within the Great Lakes basin. Tellus 30, 365-375.

O'Brien, D.M. and Wooller, M.J. 2007. Tracking human travel using stable oxygen and hydrogen isotope analysis of hair and urine. Rapid Communications in Mass Spectrometry 21, 2422-2430.

O'Connell, T.C., Hedges, R.E.M., 1999a. Isotopic comparison of hair and bone: Archaeological analyses. Journal of Archaeological Science 26, 661-665.

O'Connell, T.C., Hedges, R.E.M., 1999b. Investigations into the effect of diet on modern human hair isotopic values. American Journal of Physical Anthropology 108, 409-425.

O'Connell, T.C., Hedges, R.E.M., Healey, M.A. and Simpson, A.H.R.W. 2001. Isotopic comparison of hair, nail and bone: Modern analyses. Journal of Archaeological Science 28, 1247-1255.

O'Connell, T.C., Kneale, C.J., Tasevska, N. and Kuhnle, G.G.C. 2012. The diet-body offset in human nitrogen isotopic values: a controlled dietary study. American Journal of Physical Anthropology 149, 426-434.

O'Leary, M.H. 1988. Carbon isotopes in photosynthesis. BioScience 38, 328-333

Panzer, S., Peschel, O., Haas-Gebhard, B., Bachmeier, B.E., Pusch, C.M. and Nerlich, A.G. 2014. Reconstructing the Life of an Unknown (ca. 500 Years-Old South American Inca) Mummy - 
Multidisciplinary Study of a Peruvian Inca Mummy Suggests Severe Chagas Disease and Ritual Homicide. PLoS ONE 9(2), e89528.

Petzke, K.J. and Lemke, S. 2009. Hair protein and amino acid ${ }^{13} \mathrm{C}$ and ${ }^{15} \mathrm{~N}$ abundances take more than 4 weeks to clearly prove influences of animal protein intake in young woman with a habitual daily protein consumption of more than $1 \mathrm{~g}$ per kg body weight. Rapid Communications in Mass Spectrometry 23, 2411-2420.

Petzke, K.J., Boeing, H. and Metges, C.C. 2005a. Choice of dietary protein of vegetarians and omnivores is reflected in their hair protein ${ }^{13} \mathrm{C}$ and ${ }^{15} \mathrm{~N}$ abundance. Rapid Communications in Mass Spectrometry $19,1392-1400$.

Petzke, K.J., Boeing, H., Klaus, S. and Metges, C.C. 2005b. Carbon and nitrogen stable isotopic composition of hair protein and amino acids can be used as biomarkers for animal-derived dietary protein intake in humans. Journal of Nutrition 135, 1515-1520.

Petzke, K.J., Fuller, B.T. and Metges, C.C. 2010. Advances in natural stable isotope ratio analysis of human hair to determine nutritional and metabolic status. Current opinion in clinical nutrition and metabolic care 13, 532-40.

Petzke, K.J., Feist, T., Fleig, W.E. and Metges, C.C. 2006. Nitrogen isotopic composition in hair protein is different in liver cirrhotic patients. Rapid Communications in Mass Spectrometry 20, 2973-2978.

Privat, K.L., O'Connell, T. C. and Hedges, R. E. M. 2007. The distinction between freshwater-and terrestrialbased diets: methodological concerns and archaeological applications of sulphur stable isotope analysis. Journal of Archaeological Science 34, 1197-1204.

Raghavan, M., McCullagh, J.S., Lynnerup, N. and Hedges, R.E.M. 2010. Amino acid delta13C analysis of hair proteins and bone collagen using liquid chromatography/isotope ratio mass spectrometry: paleodietary implications from intra-individual comparisons. Rapid Communications in Mass Spectrometry 24, 541-548.

Randall, V.A. and Ebling, F.J. 1991. Seasonal changes in human hair growth. British Journal of Dermatology 124, 146-151.

Reynard, L.M. and Hedges, R.E.M. 2008. Stable hydrogen isotopes of bone collagen in palaeodietary and palaeoenvironmental reconstruction. Journal of Archaeological Science 35, 1934-1942.

Richards, M.P., Greer, S., Corr, L.T., Beattie, O., Mackie, A., Evershed, R.P., von Finster, A. and Southon, J. 2007. Radiocarbon dating and dietary stable isotope analysis of Kwaday Dän Ts'inchí. American Antiquity 72, $719-733$

Richards, M.P. Fuller, B.T. Sponheimer, M., Robinson, T. and Ayliffe, L. 2003. Sulphur isotopes in palaeodietary studies: a review and results from a controlled feeding experiment. International Journal of Osteoarchaeology 13, 37-45.

Robbins, C.R. 2002. Chemical and Physical Behavior of Human Hair. Springer-Verlag, New York.

Roy, D.M., Hall, R., Mix, A.C. and Bonnichsen, R. 2005. Using stable isotope analysis to obtain dietary profiles from old hair: A case study from Plains Indians. American Journal of Physical Anthopology 128, 444452. 
Saitoh, M., Uzuka, M., Sakamoto, M. and Kobori, T. 1969. Rate of hair growth, pp. 183-201. In: W. Montagna and Dobson, R.L. (eds.), Hair Growth. Oxford: Pergamon Press.

Schoeninger, M.J. and DeNiro, M.J. 1984. Nitrogen and carbon isotopic composition of bone collagen from marine and terrestrial animals. Geochimica et Cosmochimica Acta 48, 625-639.

Schwarczz, H.P., Dupras, T. and Fairgrieve, S.I. $1999 .{ }^{15} \mathrm{~N}$ enrichment in the Sahara: In search of a global relationship. Journal of Archaeological Science 26, 629-636

Schwarczz, H.P. and White, C.D. 2004. The grasshopper or the ant? Cultigen-use strategies in ancient Nubia from C-13 analyses of human hair. Journal of Archaeological Science 31, 53-62.

Schwertl, M., Auerswald. K. and Schnyder, H. 2003. Reconstruction of the isotopic history of animal diets by hair segmental analysis. Rapid Communications in Mass Spectrometry 17, 1312-1318.

Sealy, J. 2001. Body tissue chemistry and palaeodiet, pp. 269-279. In: Brothwell, D.R. and Pollard, A.M. (eds.), Handbook of Archaeological Sciences. London: Wiley \& Sons.

Sealy, J. C., Van Der Merwe, N. J., Lee-Thorp, J. A. and Lanham, J. L. 1987. Nitrogen isotopic ecology in southern Africa: Implications for environmental and dietary tracing. Geochimica et Cosmochimica Acta 51, 2707-2717

Sharp, Z.D., Atudorei, V., Panarello, H. O., Fernández, J. and Douthitt, C. 2003. Hydrogen isotope systematics of hair: Archaeological and forensic applications. Journal of Archaeological Science 30, 1709-1716.

Smith, C.I., Fuller, B.T., Choy, K. and Richards, M.P. 2009. A three-phase liquid chromatographic method for $\delta^{13} \mathrm{C}$ analysis of amino acids from biological protein hydrolysates using liquid chromatographyisotope ratio mass spectrometry. Analytical Biochemistry 390, 165-172.

Sponheimer, M., Robinson, T., Ayliffe, L., Roeder, B., Shipley, L., Lopez, E., West, A., Hammer, J., Passey, B., Cerling, T., Dearing, D. and Ehleringer, J. 2003. An Experimental Study of Carbon Isotopes in the Diets, Feces, and Hair of Mammalian Herbivores. Canadian Journal of Zoology 81, 871-876.

Thompson, A.H., Chaix, L. and Richards, M.P. 2008. Stable isotopes and diet at Ancient Kerma, Upper Nubia (Sudan). Journal of Archaeological Science 35, 376-387.

Thompson, A.H., Chesson, L.A., Podlesak, D.W., Bowen, G.J., Cerling, T.E. and Ehleringer, J.R. 2010. Stable isotope analysis of modern human hair collected from Asia (China, India, Mongolia, and Pakistan). American Journal of Physical Anthropology 141, 440-451.

Thompson, A.H., Richards, M.P., Shortland, A. and Zakrzewski, S.R. 2005. Isotopic palaeodiet studies of Ancient Egyptian fauna and humans. Journal of Archaeological Science 32, 451-463.

Thompson, A.H., Wilson, A.S. and Ehleringer, J.R. 2014. Hair as a Geochemical Recorder: Ancient to Modern, pp. 371-393. In Cerling, T.E. (ed.) Treatise on Geochemistry (volume 14): Archaeology \& Anthropology. 2nd ed. Cambridge: Elsevier.

Tieszen, L.L. and Fagre, T. 1993. Effect of diet quality and composition on the isotopic composition of respiratory CO2, bone collagen and soft tissues, pp. 121-155. In Lambert, J.B. and Grupe, G.G. (eds.) Prehistoric Human Bone: Archaeology at the Molecular Level. Berlin: Springer-Verlag. 
Tieszen, L.L., Boutton, T.W., Tesdahl, K.G. and Slade, N.A. 1983. Fractionation and turnover of stable carbon isotopes in animal tissues: Implications for $\delta^{13} \mathrm{C}$ analysis of diet. Oecologia 57, 32-37.

Tieszen, L.L., Iversen, E., and Matzner, S. 1995, Dietary reconstruction based on carbon, nitrogen, and sulfur stable isotopes in the Atacama Desert, northern Chile, pp 427-441. In Aufderheide, A.C. and Martin, C.R. (eds.), World congress on mummy studies, 1992, Proceedings: Tenerife, Museo Arquelógico y Etnográfico de Tenerife, Organismo Autónomo de Museos y Centros.

Touzeau, A., Amiot, R., Blichert-Toft, J., Flandrois, J., Fourel, F., Grossi, V., Martineau, F., Richardin, P. and Lécuyer, C. 2014. Diet of ancient Egyptians inferred from stable isotope systematic. Journal of Archaeological Science 46, 114-124.

Turner, B., Klaus, H., Livengood, S., Brown, L., Saldaña, F. and Wester, C. 2013. The variable roads to sacrifice: Isotopic investigations of human remains from Chotuna-Huaca de los Sacrificios, Lambayeque, Peru. American Journal of Physical Anthropology 151, 22-37.

Turner, B.L., Zuckerman, M.K., Garofalo, E.M., Wilson, A.S., Kamenov, G.D., Hunt, D.R., Amgalantugs, T. and Frohlich, B. 2012. Diet and death in times of war: isotopic and osteological analysis of mummified human remains from southern Mongolia. Journal of Archaeological Science 39, 3125-3140.

Tykot, R.H., Metroka, A., Dietz, M. and Bergfield, R.A. 2011. Chemical Analysis of Hair Segments and ShortTerm Dietary Variation: Results for the Ancient Site of Chongos (Peru), pp. 441-446. In TurbantiMemmi, I. (ed.), Proceedings of the $37^{\text {th }}$ International Symposium on Archaeometry. Berlin: SpringerVerlag.

Wassenaar, L.I. and Hobson, K.A. 2002. Comparative equilibration and online technique for determination of non-exchangeable hydrogen of keratins for use in animal migration studies. Isotopes in Environmental and Health Studies 39, 1-7.

Webb, E. C., White, C. D. and Longstaffe, F. J. 2013b. Exploring Geographic Origins at Cahuachi using Stable Isotopic Analysis of Archaeological Human Tissues and Modern Environmental Waters. International Journal of Osteoarchaeology 23, 698-715.

Webb, E., White, C. and Longstaffe, F. 2013a. Dietary shifting in the Nasca Region as inferred from the carbon- and nitrogen-isotope compositions of archaeological hair and bone, Journal of Archaeological Science 40, 129-139.

White, C.D. 1993. Isotopic determination of seasonality of diet and death in ancient Nubian hair. Journal of Archaeological Science 20, 657-666.

White, C.D. and Schwarczz, H.P. 1989. Ancient Maya diet: as inferred from isotopic and elemental analysis of human bone. Journal of Archaeological Science 16, 451-474.

White, C.D. and Schwarczz, H. P. 1994. Temporal trends in stable isotopes for Nubian mummy tissues. American Journal of Physical Anthropology 93, 165-187.

White, C.D., Longstaffe, F.J. and Law, K.R. 1995. Isotopic analysis of hair and skin from Kharga Oasis mummies. Unpublished report to the American Museum of Natural History.

White, C.D., Longstaffe, F.J. and Law, K.R. 1999. Seasonal stability and variation in diet as reflected in human mummy tissues from the Kharga Oasis and the Nile Valley. Paleogeography, Paleoclimatology, 
Palaeoecology 147, 209-222.

White C.D., Nelson, A.J., Longstaffe, F.J., Grupe, G. and Jung, A. 2009. Landscape bioarchaeology at Pacatnamu, Peru: inferring mobility from $\delta 13 \mathrm{C}$ and $\delta 15 \mathrm{~N}$ values of hair. Journal of Archaeological Science 36, 1527-1537.

Williams, J.S. and Katzenberg, M.A. 2012. Seasonal fluctuations in diet and death during the late horizon: a stable isotopic analysis of hair and nail from the central coast of Peru. Journal of Archaeological Science 39, 41-57.

Williams, L.J. 2008. Investigating Seasonality of Death at Kellis 2 Cemetery Using Solar Alignment and Isotopic Analysis of Mummified Tissues. Unpublished PhD. University of Western Ontario, London.

Williams, L.J., White, C.D. and Longstaffe. F.J. 2011. Improving stable isotopic interpretations made from human hair through reduction of growth cycle error. American Journal of Physical Anthropology 145, 125-136.

Wilson, A. S., Edwards, H.G.M., Farwell, D.W. and Janaway, R. C. 1999. Fourier Transform Raman Spectroscopy: Evaluation as a Non-Destructive Technique for Studying the Degradation of Human Hair from Archaeological and Forensic Environments. Journal of Raman Spectroscopy 30, 367-373.

Wilson, A. S., Dixon, R. A. Edwards, H.G.M., Farwell, D.W., Janaway, R. C., Pollard, A.M. and D. J. Tobin, D.J. 2001. Towards an understanding of the interaction of hair with the depositional environment. Chungara: Revista de Antropología Chilena 33, 293-296.

Wilson, A.S., Dodson, H.I., Janaway, R.C., Pollard, A.M. and Tobin, D.J. 2010. Evaluating histological methods for assessing hair fibre degradation. Archaeometry 52, 467-481.

Wilson, A. S., Meier-Augenstein, W., Taylor, T., Ceruti, M. C., Chavez, J. A., Reinhard, J. And Gilbert, P. 2007. Stable isotope and DNA evidence for ritual sequences in Inca child sacrifice. Proceedings of the National Academy of Sciences 104, 16456-16461.

Zaias, N. 1980. The Nail in Health and Disease. Springer, Netherlands 439pp. 


\begin{tabular}{|c|c|c|c|c|c|c|c|c|c|c|c|c|c|}
\hline Location & Tissue & Site & Age & $\begin{array}{l}\delta^{13} \mathrm{C} \\
\text { v-PDB }\end{array}$ & $\begin{array}{l}1 S D \\
\delta^{13} C\end{array}$ & $\begin{array}{l}\delta^{15} \mathrm{~N} \\
\text { AIR }\end{array}$ & $\begin{array}{l}1 S D \\
\delta^{15} N\end{array}$ & $\begin{array}{l}\delta^{34} S \\
v-C D T\end{array}$ & $\begin{array}{l}1 S D \\
\delta^{34} S\end{array}$ & $\begin{array}{l}\delta^{18} O \\
v- \\
\text { SMOW }\end{array}$ & $\begin{array}{l}1 S D \\
\delta^{18} O\end{array}$ & $\begin{array}{l}\delta^{2} \mathrm{H} \\
v- \\
\text { SMOW }\end{array}$ & $\begin{array}{l}1 \text { SD } \\
\delta D\end{array}$ \\
\hline \multicolumn{14}{|l|}{ Egypt } \\
\hline Macko et al. 1999a & Hair & unknown $(n=9)$ & Late Middle Kingdom & -21.5 & 1.1 & 14.0 & 1.1 & & & & & & \\
\hline White et al. 1999 & Skin & Kharga Oasis $(n=4)$ & 25th Dynasty - Coptic Period & -20.4 & 0.6 & & & & & & & & \\
\hline White et al. 1999 & Hair & Kharga Oasis $(n=22)$ & 25th Dynasty - Coptic Period & -19.6 & 0.5 & & & & & & & & \\
\hline Touzeau et al. 2014 & Hair & Gournah \& Thebes $(n=5)$ & 26th Dynasty & -19.8 & 0.4 & 12.9 & 2.2 & 8.1 & 0.7 & & & & \\
\hline Touzeau et al. 2014 & Hair & Thebes $(n=1)$ & Ptolemaic & -19.9 & & 11.8 & & 8.4 & & & & & \\
\hline Touzeau et al. 2014 & Hair & Antinopolis $(n=3)$ & $\mathrm{CO}$ & -20.3 & 0.2 & 10.4 & 1.1 & 10.4 & 0.8 & & & & \\
\hline \multicolumn{14}{|l|}{ Asia } \\
\hline Turner et al. 2012 & Hair & Southern Mongolia $(n=4)$ & AD 1434-1651 & -16.9 & 0.4 & 12.9 & 1.2 & & & & & & \\
\hline \multicolumn{14}{|l|}{ Nubia/Sudan } \\
\hline White 1993 & Hair & Wadi Halfa (n=9) & X-Group (350-550 AD) & -16.6 & 1.9 & & & & & & & & \\
\hline White 1993 & Hair & Wadi Halfa $(n=5)$ & Christian (500-1400 AD) & -16.7 & 2.3 & & & & & & & & \\
\hline White et al. 1995 & Skin & Wadi Halfa $(n=14)$ & X-Group/Christian (350-1400 AD) & -18.6 & & & & & & & & & \\
\hline White \& Schwarcz 1994 & Muscle & Wadi Halfa (C: $n=25, N: n=21)$ & X-Group (350-550 AD) & -16.5 & 2.0 & 13.0 & 1.2 & & & & & & \\
\hline White \& Schwarcz 1994 & Muscle & Wadi Halfa (C: $n=8, N: n=3$ ) & Christian (500-1400 AD) & -19.5 & 0.8 & 14.6 & 1.6 & & & & & & \\
\hline White \& Schwarcz 1994 & Skin & Wadi Halfa (C: $n=39, N: n=32$ ) & X-Group (350-550 AD) & -17.6 & 1.8 & 14.0 & 1.4 & & & & & & \\
\hline White \& Schwarcz 1994 & Skin & Wadi Halfa (C: $n=17, N: n=16)$ & Christian (500-1400 AD) & -19.5 & 2.7 & 13.2 & 1.6 & & & & & & \\
\hline White \& Schwarcz 1994 & Hair & Wadi Halfa $(n=19)$ & X-Group (350-550 AD) & -15.5 & 3.4 & & & & & & & & \\
\hline White \& Schwarcz 1994 & Hair & Wadi Halfa $(n=8)$ & Christian (500-1400 AD) & -14.3 & 5.2 & & & & & & & & \\
\hline lacumin et al. 1998 & Skin & Kerma, N Sudan (n=7) & Various & -17.5 & 3.6 & 15.8 & 2.3 & & & & & & \\
\hline \multicolumn{14}{|l|}{ South America } \\
\hline Aufderheide et al. 1994 & Hair & Pisagua, North Chile $(n=9)$ & Early Alto Ramirez (1000 BC) & -13.9 & 1.2 & 25.0 & 1.5 & 17.3 & 1.0 & & & & \\
\hline Aufderheide et al. 1994 & Muscle & Pisagua, North Chile (n=9) & Early Alto Ramirez (1000 BC) & -16.3 & 1.8 & 28.8 & 3.0 & & & & & & \\
\hline Wilson et al. 2007 & Hair & High Andes $(n=4)$ & Late Horizon (AD 1476-1532) & -16.0 & 2.3 & 9.0 & 2.1 & 8.1 & 3.1 & 5.2 & 1.6 & -111.7 & 13.5 \\
\hline
\end{tabular}




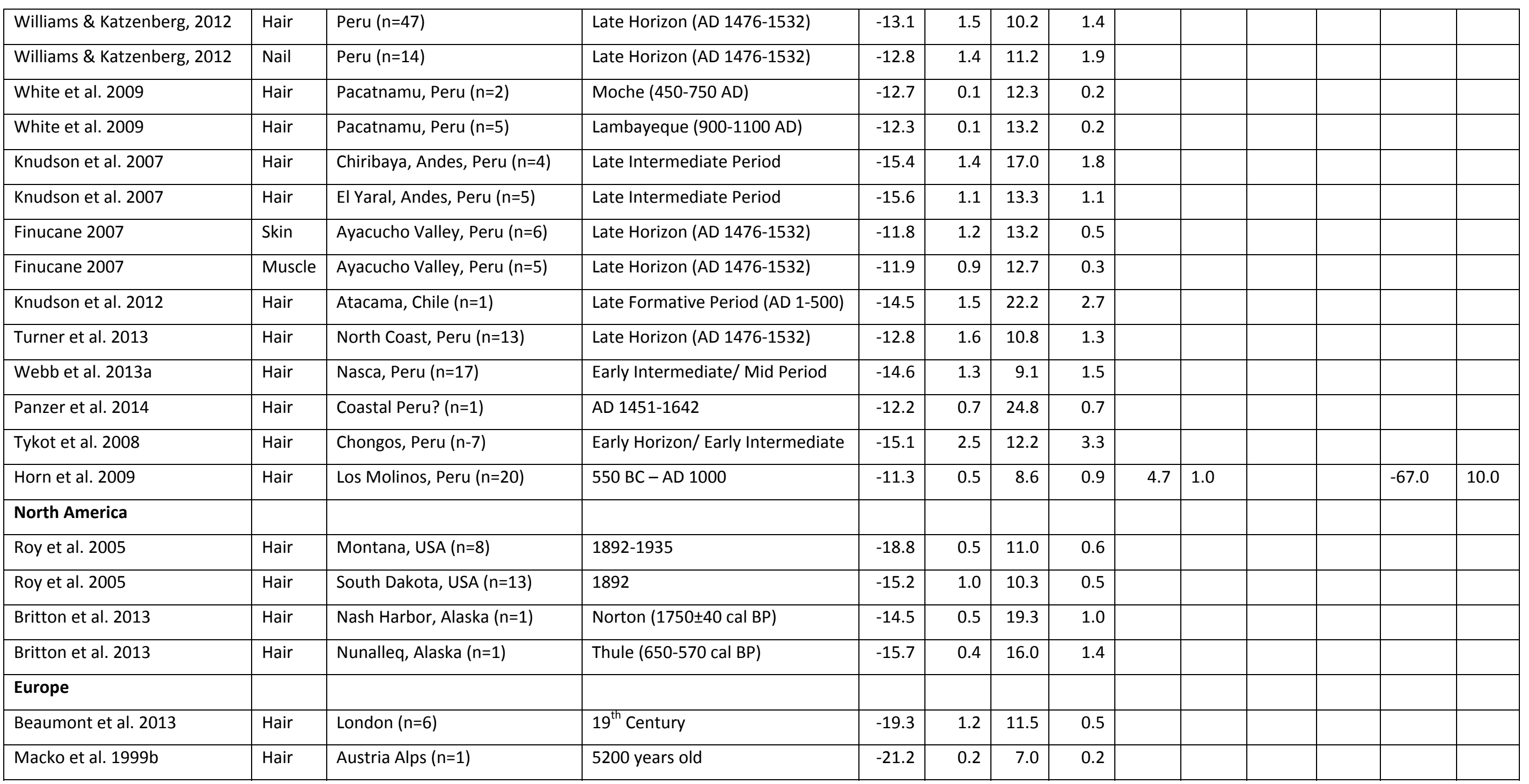

